\title{
The Name Alaska
}

\section{GEORGE R. STEWART}

T

he Territory of Alaska - destined soon, we all hope, to become a state - possesses in its name a heritage equaling in the interest of its historical development even such unusual state names as California, Oregon, and Vermont.

Dall gives Alaska as derived from an Aleut root meaning "a great country or continent." (W. H. Dall, Alaska and its Resources, 1870, page 529-530). Baker states that the name is "a corruption of some native word or phrase, the meaning of which is uncertain." (Marcus Baker, Geographic Dictionary of Alaska, Second Edition, 1906, page 89.) The Handbook of American Indians (Ed. F. W. Hodge, 1907-10, under entry Alaskaite) cites Dall to the effect that the name signifies "mainland." A Guide to Alaska (Merle Colby, Ed., 1939, page 332) states somewhat vaguely, "al-ay-ek-sha is supposed to mean 'mainland,' and even today Natives of the Shumagins are reported as saying, when they intend to cross over to the peninsula, 'I am going to Alaska' (i. e., the mainland)."' Ransom meticulously analyses the word in Aleut, and arrives at the conclusion that it means "mainland." (J. Ellis Ransom, American Anthropologist, N. S. vol. xlii, July-September 1940, pages 550-1). Linguistic arguments, therefore, seem to favor the acceptance of "mainland," or "continent."

From an onomastic point of view this meaning is acceptable. Where islands lie off the coast, some such generic term is likely to be applied, and this sometimes hardens into a true place name, especially when a shift of language is involved. The Greek name Epirus is thus to be explained, and probably Maine in the United States. ${ }^{1}$

1 Although I am ready to accept the conclusions of such com petent authorities as Dall and Ransom, I would feel more comfortable if a better explanation of the name Unalaska could be produced. This seems to contain the same root as Alaska, 
In popular usage, Alaska is frequently said to mean the "big country," or the "great land." These might be thought to be merely somewhat fanciful interpretations of "mainland." More likely, however, they are independently derived, and the historical background calls for brief presentation.

Having reached eastern Siberia, the Russians began to hear of a "great land," lying across the sea still farther to the east. Such reports were being collected as early as 1711 (H. H. Bancroft, History of Alaska, 1886, pages 26-27). The Russian words used are simply bolshaya zemlya, from which there is no possibility of deriving Alaska. The informants of the Russians were of the local Chukchi tribe. As far as I have been able to discover, the Chukchi words which the Russians translated as bolshaya zemlya have not been preserved. There is, therefore, no reason to think that they were anything that sounded like Alaska. Moreover, the Russian advance and the resulting establishment of the name occurred, not from the Chukchi country, but from the Aleutian Islands. There is, therefore, every reason to reject any derivation of the name from the Chukchi source, and accordingly the literal meaning "great land."

The Russian use of the name Alaska begins about 1760, in connection with some voyages recorded in the anonymous German work Neue Nachrichten von denen neuentdekten Insuln (1776). Here we read (page 53) of an island "Alaeksu" or "Alachschak." Again (page 56) we have "Alaesku," described as an island close to the mainland, but not the mainland. "Alaeksu" is more definitelydescribed and located (page 115) as the large island lying north of Kadjak. Since Kadjak is undoubtedly to be identified with the modern Kodiak, Afognak Island might fill the requirements. But Afognak, though some fifty miles across, is much smaller than Kodiak itself, and is separated from the larger island by only a narrow channel. It would seem, then, scarcely to warrant the description. There is, moreover, nothing else to indicate that the name Alaska was ever applied to Afognak. Much more likely, the German writer erred in assuming that Alaeksu was an island.

and yet is an island. Dall (loc. cit.) explains it as being "the land near Aláyeksa." But this is geographically unsatisfactory, since Unalaska is several islands removed from being the closest one to the mainland. 
Probably it was what is now known as the Alaska Peninsula, the base of which lies north of Kodiak. This is the particular region to which the name Alaska was certainly applied in slightly later times.

Coxe (William Coxe, Account of the Russian Discoveries, 1780), describing voyages of the seventeen-sixties, refers to the island "Alaksu, or Alachshak" (page 65), and also of another island "Alaxa" (page 254, 345), but also states (page 65, note) that the two are probably the same. In this connection his map of Krenitzen's and Levasheff's voyage (inserted at page 251) is of interest. This shows Alaxa as an island lying northeast of Unimak, from which it is separated by a narrow channel. Since Unimak is the island closest to the mainland, this would indicate definitely that Alaxa was part of the mainland, though the Russians and Coxe, with their limited geographical horizon, assumed it to be another island.

On what is generally known as Staehlin's map (included in J. Von Staehlin, An Account of the New Northern Archipelago, English edition, 1774.) Alaschka appears as a large island extending east and west in Latitude $65^{\circ}$. Captain Cook on his voyage of 1778 hunted conscientiously for this island, but naturally was unable to find it. (A Voyage to the Pacific Ocean, 1785, vol. ii, page 474.)

Cook's findings, or lack of findings, led Coxe to a new statement in the revision of his work published in 1787 as $A$ Comparative View of the Russian Discoveries: "Alaxa, called sometimes Alaxsu, Alachshak and Alashka, ... supposed to be a great island in the vicinity of America, was found by Cook to be a promontory of that Continent." (page 15.)

After this time, since there was no island to which it could be applied, Alaska came to be generally used for what is now known as the Alaska Peninsula, which we must believe, indeed, to have been its original application. Such usage merely reflected geographical actualities and the local manner of speech among the Russians and Aleuts. Cook had noticed this custom, as he reported, "I have already observed, that the American continent is here called, by the Russians, as well as the islanders, Alaschka; which name, though it probably belong only to the country adjoining to Oonemak, is used by them in speaking of the American continent in general, which they know perfectly well to be a great land." (Cook, op. cit., vol. ii, page 504). 
Because of Cook's great prestige, his observation that Alaschka was sometimes used to refer to the continent was of importance in determining the later history of the name. His reference to "a great land" may be an echo of the earlier usage already mentioned.

In general, from Cook's time to that of the American occupation was a period of quiescence. Russian America was officially established as the name for the whole territory, and Alaska was thus more definitely than ever restricted to the peninsula.

An interesting irony exists in connection with Cook's use of the name. As his own words seem to indicate, he was - not unnaturally - somewhat irritated at having been forced to look for a nonexistent island, and he apparently resented the application of the name to the "continent in general," doubtless thinking that it should merely be called North America. Yet this passage was later to be quoted (see below) as authority for the wider application. Moreover, though Cook always used the spelling Alaschka, he was to be cited as the authority for Alaska (see below).

In reading pre-1867 works, one must be on guard against assuming that Alaska, however spelled, is to be taken in its modern sense. Kotzebue, for instance, once refers to "the islands lying to the north of Alaska." (Otto von Kotzebue, A Voyage of Discovery into the South Sea and Beering's Straits, English translation, 1821, vol. ii, page 164). Since there are no such islands, if the name is conceived in the modern sense, and since Kotzebue had no idea that there were any such, the reference here must be to the islands of Bering Sea, which may be said to lie to the north of the Alaska Peninsula. Again, Kotzebue refers to "the continent of Alaschka," (op. cit., vol ii, page 185). An analysis of the passage, however, seems to indicate that he is again referring to the peninsula, though the language (at least in the translation) is not very clear.

The legend "Probincia [sic] de Alaska" on a Spanish map of 1791 is unique in its implication that the name could be applied to a region or province. Since this map exists only in manuscript, it cannot have been of any important influence. (See H. R. Wagner; Cartography of the Northwest Coast of America, 1937, vol. ii, pages $372,355)$.

During this whole period, except as a local name, Alaska definitely was given the cold shoulder by geographers. To them the whole area was simply a part of the American continent, and the 
use of any other name undoubtedly seemed to them to be giving encouragement to such myths as that of the large island of Alaska, laboriously exploded by $\mathrm{Cook}^{2}$.

One accomplishment of the early nineteenth century was the simplification of the spelling. Before 1800 , as our citations sufficiently demonstrate, almost any kind of spelling is to be expected. By 1850 the variants have been reduced to Alaska and Aliaska - at least in an English-language context. Of these, the former was more common.

Map-makers placed the name on the peninsula, but often wrote the name alone, as if it indicated not a geographical feature but a district. Thus, for instance, it appears, in Mitchell's Modern Atlas, published in Philadelphia, in 1866, and therefore a really up-to-date map at the time of the purchase.

In 1867 the situation was suddenly changed. In that year, as every schoolboy may be expected to know, "the United States purchased Alaska." Actually, this is a far from accurate statement. The United States purchased Alaska only because it happened to be a small part of the whole area. What was really purchased was Russian America.

Even this term was not ised in the treaty, but in that document the real estate to be transferred was described only as "all the territory and dominion now possessed by his said majesty [the Emperor of all the Russias] on the continent of America and in the adjacent islands."

At this point a problem arose. The United States purchased Russian America, but by that very transaction the territory in question ceased to be Russian America. A new name, therefore, was necessary.

A period of uncertainty and transition ensued, covering inuch of 1867. The process can be traced in the pages of the Alta California, a leading journal of San Francisco, a city much concerned with the new purchase. Interest began to display itself with editorials on

\footnotetext{
${ }^{2}$ In this connection, it might be noted that voyagers in this area regularly referred to the natives (whether Eskimos, Aleuts, or Indians) as Americans. This sometimes produces a startling effect for the modern American reader.
} 
April 3 and 4; both referred to "Russian America," with no mention of any other name. On April 8 an editorial referred to "the peninsula of Alaska," thus indicating that the name was still so restricted. On April 11, came the first fumbling for a new name, in the words, "Russian America - we shall call it the Territory of Alexander." The use of this last name is an interesting indication of the popularity of the czar on account of his support of the United States during the Civil War. The Alta, however, reverted to its earlier usage, without question, until June 3, when doubt was again expressed by the insertion after Russian America of the words "(or what shall we call it?)"

June 17 saw the first use of Alaska as a general name, with an editorial entitled "Alaska minerals." In the editorial itself, both Russian America and Alaska were used. June 27 provided the utmost confusion when Alaska was used in the title of an article in the body of which occurred the words "that portion of the Northwest Coast, or Russian American possessions." July 4 saw another mention of Alaska, only to be followed on July 7, by Russian America. This last, however, seems to have been the final use of the old term, and on July 10 there is a definite reference to the "new Territory of Alaska." From here on, the use of Alaska is regular.

To complete the story, however, one should include from the issue of July 21 the words, "our new territorial acquisition of Alaska, or as it is now sornetimes called, Walrussia." This last was the coinage of some wit, and had wide humorous circulation at the time. Needless to say, it should not be taken seriously as a proposed name for the new territory.

The New York Times moved more rapidly. On May 3 it offered a heading, "Notes on Alaska." From that time on, it seems regularly to have used that name. This difference in usage probably indicates that the new form was accepted sooner in the East than in the West.

Official adoption of the new name lagged behind its use in the newspapers. President Johnson, in his message to the Congress on July 6 gave no name at all. Already, however, various names had been proposed in governmental circles, and at least three official sponsors must be considered.

1. Seward. In the biography of William H. Seward by his son (F. W. Seward, Seward at Washington, 1891, page 369) the state- 
ment appears that various names had been suggested - Sitka, Yukon, Aliaska, Alaska, Oonalaska, Aleutia, ${ }^{3}$ but that "Seward, with whom the final decision rested, preferred Alaska," as being "brief, euphonious, and suitable."

There is nothing inherently unlikely in Seward's having proposed the name, but this claim of a son-biographer presented twentyfour years later is not supported by citation of contemporary documents, and I have come across none which would indicate that Seward was the proposer of the name. That neither Sumner nor Halleck (see below) gives any acknowledgment to Seward would indicate the contrary.

In any case the statement that the "final decision" rested with Seward must be challenged. Although he had negotiated the treaty, there is nothing in the history of the time to indicate that the Secretary of State had any authority at all, much less the "final decision", as to the name of a new territory. During the whole decade of the sixties Congress was very active in establishing the names of territories. The case for Seward, though possible, cannot be shown to rest on contemporary evidence.

2. Sumner. The claims of Senator Charles Sumner as the proposer of the name are extremely strong. Sumner was informed of the impending purchase on March 29, 1867, shortly before the signing of the treaty. As chairman of the Committee on Foreign Relations, he supported ratification, and on April 9 he spoke "on the negotiation, its origin, and the character of the ceded possessions," (Works of Charles Sumner, vol. xi, 1877, page 184). If we knew what he said on that occasion, the matter might be definitely settled. Unfortunately the Senate was then in Executive Session; no reporters were present, and the actual speech is not preserved. As the passage continues: "Senators interested in the question invited Mr. Sumner to write out his remarks and give them to the public. For some time he hesitated, but, taking ad-

\footnotetext{
${ }^{3}$ Aside from this passage I have not come across these suggestions, except that Yukon Territory seems to be implied, though not definitely suggested, by its use in Dall's work, which he actually called Alaska and its Resources. The sources of these names are obvious. Oonalaska was better known than other names of the region because of its use in Thomas Campbell's famous line of The Pleasures of Hope: "The wolf's long howl from Oonalaska's shore." (As Sumner was keen enough to point out, the wolf is actually not found in the Aleutians.)
} 
vantage of the vacation, he applied himself to the work, following precisely in order and subdivision the notes on a single page from which he spoke." The result was the well-known document The Cession of Russian America to the United States, sub-titled, Speech in the Senate, ... April 9, $186 \%$.

But this so-called speech is really a long and learned monograph running to 164 pages in the Works, and based upon practically all the known publications about Russian America. Even with good secretarial help, a busy senator could not have completed so much research in ten days. The speech could not possibly have been delivered from one page of notes, and the amount of business transacted by the Senate that day shows that the Senators could not also have listened through the three or four hours which Sumner would have required to deliver his oration.

The point of discussing the matter is that the printed version contains a passage which is worth quoting in extenso, both as an example of thought about names at the time and as a suggestion of the name Alaska:

As these extensive possessions, .... pass from the imperial government of Russia, they will naturally receive a new name. They will be no longer Russian America. How shall they be called ? Clearly, any name borrowed from classical antiquity or from individual invention will be little better than misnomer or nickname unworthy of the historic occasion. Even if taken from our own annals, it will be of doubtful taste. The name should come from the country itself. It should be indigenous, aboriginal, one of the autochthons of the soil. Happily such a name exists, as proper in sound as in origin. It appears from the report of Cook, ... that the euphonious designation now applied to the peninsula ... was the sole word used originally by the native islanders, "when speaking of the American continent in general, which they knew perfectly well to be a great land." It only remains, that, following these natives, whose places are now ours, we, too, should call this "great land" Alaska. (op. cit., page 347)

In commenting on this passage we must cast some aspersions on Senator Sumner's much-vaunted scholarship. Not only does he write "knew" for "know", but also in his note he gets the pagereference wrong. Moreover, he at least implies that Cook used Alaska, whereas Cook spelled it Alaschka. 
All caviling aside, Sumner's case is very strong, even if he did not write the passage until shortly before its publication on May 25. In any case, since copies of his "speech" circulated widely, he must have exercized a great influence in establishing the use of the name.

A year later, on May 8, 1868, Sumner wrote a letter to "Hon. Hiram Barney," in which he again discussed the name, chiefly in relation to the other form, Aliaska. He stated, in part (op. cit., page 348 , note):

Looking for a name, my attention was arrested by the designation of the promontory stretching to the Aleutian Islands, called by Captain Cook, the first Englishman who visited the region, Alaska, without an $i$, as the large and neighboring island was called Oonalaska. This is the first time, so far as I am aware, that the name appears. Though at a later day it was sometimes written 'Aliaska,' it seemed to me that the earlier designation was historically more just, while in itself a better word. On this account, at the close of my speech I ventured to propose it as a name for the whole country.

Again some inaccuracies are to be noted. Sumner, having cited Coxe in his "speech," should have known that Cook was not the first to use the name. Moreover, Sumner here definitely but incorrectly cites Cook as having used the spelling Alaska. Sumner's words, "at the close of my speech,". do not really change the situation. Though "close" may seem more fitted to oral than to written presentation, Sumner was thinking in terms of what was being generally called a "speech." Besides, after the lapse of a year, he might well have forgotten.

Of even more interest is the final paragraph of this letter:

While I was doing this [i. e., proposing the name] in Washington, General Halleck, in San Francisco, was writing an elaborate letter to the Government about the new territory, in which he proposed the same name, with, as I understand, the same spelling.

This brings us to the third claimant.

3. Halleck. Major General H. W. ("Old Brains") Halleck had been Chief of Staff during the Civil War, and in 1867 commanded the Military Division of the Pacific. On May 22 of that year, he wrote from his headquarters in San Francisco to Brevet Major General E. D. Townsend in the Adjutant General's Office a long letter (See 40 th Cong., 2 Sess., H. R. Ex. Doc. No. 117, pages $57-58)$ containing the interesting passage: 
I learn from Colonel Bulkley, and find his statements confirmed by the printed reports of earlier explorers, that the word "Alaska" is applied by the natives and Russians to most of the ceded territory, usually called by us "Russian America." . . I It is understood that the term Alaska (erroneously written in some recent maps Aliaska, which letters do not properly represent the sound of the word) is used by the natives and Russian settlers to include or apply to all the Russian possessions on the American continent.

I therefore respectfully recommend that this name "Alaska" be employed to designate the military district or department which may be organized there, and also the civil territorial government, should one be organized by Congress for that country. Other terms have been proposed in newspaper articles, but they do not seem to me as appropriate as this word.

The letter calls for some comment. C. S. Bulkley, Engineer-inChief of the Western Union explorations in Canada and Russian America, was in a position to know what he was talking about, but I have found nothing else to suggest the usage of Alaska which he here indicates. By "earlier explorers" Halleck doubtless means Cook. I have found no others who might be quoted to the same effect. Halleck himself runs into inconsistency by first writing that "most of the ceded territory" is so called, and in the same paragraph that the name is applied "to all the Russian possessions."

Such small matters aside, one should note that Halleck seems in ignorance that Sumner had suggested Alaska. If Sumner had actually been advocating the name since April 9, we should expect that some word of it would have come to Halleck through the newspapers or by other means.

Not only was Halleck a prominent figure, but also he was in a strategic position as commanding general of the Division of which Alaska was to be a part. His letter could hardly have been ignored.

Finally it is of interest that Sumner - not a man addicted to excessive self-effacement - gives a kind of equal credit to Halleck. This is a strong argument against Sumner's having included the name-passage in his actual speech, which antedated Halleck's letter by six weeks. On the other hand, the dates of the letter (May 22) and of the publication day of the "speech" (May 25) are almost the same.

However the name may have been suggested, no act was passed at this time to set up a new territory officially. And so there was 
no definite authorization of a new name. Alaska seems to have established itself gradually. In a letter of October $26, \mathrm{O} . \mathrm{H}$. Browning, Secretary of the Interior, used both "territory of Alaska," and "Russian purchase." Two days later, Seward used the simple "Alaska" in a letter to General Grant, then Secretary of War. Scattered references to Alaska can be found in official correspondence at somewhat earlier dates. Probably, however, we can consider that the new name was firmly established in October.

The highly informal procedure is unusual and surprising, in view of the fact that at this period Congress had become very conscious of names and even jealous of its prerogative of naming new territories. (On this point see my Names on the Land, 1945, pages 301-314.) The failure of Congress to do anything about a name may be attributed to two causes. First, there was a transition period of some months between the signing of the treaty and the actual raising of the flag at Sitka. During this time the government could take no action because the purchase was not yet surely a part of the United States. Second, Alaska was not established as a territory until many years later. The question of its naming thus did not come before the Committee on Territories or before Congress.

On the basis of materials available, my own conclusion is that the name established itself by a kind of anonymous process of folk-selection. Sumner certainly had a hand in it; so did Halleck; so, quite possibly, did Seward; and so, in all likelihood, did a lot of other people. We should remember that the New York Times was using Alaska three weeks before the writing of Halleck's letter or the publication of Sumner's "speech."

Once Russian America had become inapplicable, numerous people - journalists and others - must have looked at their maps to see what other names were available. At this time Indian names were very popular. Anyone thus looking at a recent map would have seen the name Alaska in a fairly prominent position. It thus served the need excellently - an aboriginal name, somewhat vaguely applied, not confined within precise boundaries, readily expandible to cover the whole area.

In this last connection some historical analogies may be offered. A peninsula is not so perfectly delineated as is an island, and there is often a tendency for its name to be extended more widely around 
its base. Thus Italy was at first applied only to a small southern section. In the same way Florida and California have exceeded their original peninsular limits. Alaska offers another striking example of the process.

The present essay has been able, I hope, to present the general outlines of the process by which Alaska has become a notable name; some details of the process remain to be filled in. As a concluding word, we may note that once Alaska has gained statehood it will not only add one more to the twenty-six present names of states derived from native American languages; but also will add something new. The present names are derived from several different linguistic stocks - Algonquian, Iroquoian, Siouan, Muskogean and others. Alaska will add a name from the Aleutian language of the Eskimo linguistic stock.

Drummers and Dreamers is the title of a book published by our member Click Relander, city editor of the Yakima Daily Republic, and well-known historian, author, and sculptor. It is a fascinating account of the Indian tribes of the Wanapums in Washington, with numerous illustrations, including some photographs of Indian sculptures by the author. Mechanically, the book is a well-nigh perfect job of The Caxton Printers. Since the book contains a wealth of information on names we shall publish an extensive review in one of the next issues. 